Седікова Ірина Олександрівна доктор економічних наук, професор кафедри менеджменту і логістики Одеської національної академії харчових технологій , вул. Канатна, 112, м. Одеса, 65039, тел.: (048) 712-41-14, e-mail: irinasedikova@ukr/net, https://orcid.org/0000-0001-5684-6927

Ніколюк Олена Володимирівна доктор економічних наук, професор кафедри менеджменту і логістики Одеської національної академії харчових технологій , вул. Канатна, 112, м. Одеса, 65039, тел.: (048) 712-41-14, e-mail: alenavn11@gmail.com, https://orcid.org/0000-0002-1665-0361

\title{
МІГРАЦІЙНІ ОСВІТНІ ПРОЦЕСИ В УКРАЇНІ
}

Анотація. Стаття присвячена аналізу освітньої міграції в світі та Україні. На думку авторів, освітня імміграція має величезне соціальне значення для багатьох країн, зокрема, несе, як мінімум, чотири ключових ефекти: соціальний, політичний, демографічний і економічний.

Процес вибору професії, навчання у ЗВО став сьогодні для багатьох студентів прагматичним, цілеспрямованим і відповідним змінам, що відбуваються у суспільстві. Залучаючи переважно молодих, добре освічених людей, міграційні процеси сприяють підвищенню освітнього потенціалу населення регіонівреципієнтів і зниженню показників досягнутого освітнього рівня в регіонахдонорах. Для перспективної молоді еміграція залишається чи не єдиним шляхом швидкого поліпшення добробуту без відмови від наукової діяльності.

В умовах посилення міграційних потоків у світовому масштабі освітніх мігрантів можна вважати найбажанішою категорією, оскільки, як правило, іiі складають молоді та ініціативні люди, які відрізняються відкритістю і готовністю сприймати нові знання, технології, які отримують національну освіту та кваліфікацію, пристосовані до місцевого ринку праці, адаптовані до мовного та культурного середовища. Систематизація теоретичних підходів до вивчення даного процесу і дослідження тенденцій міграційних переміщень дозволили автору не тільки виявити особливості освітньої міграції в сучасному світі, а й встановити транснаціональні перспективи ії розвитку.

У статті досліджено головні причини, що лежать в основі сучасної освітньої міграції, зокрема, отримання вищої освіти в зарубіжних навчальних закладах. Автори розглядають сучасний стан освітньої міграції, значення експорту українських здобувачів вищої освіти на ринок європейських країн. В якості методів даного дослідження був використаний теоретичний аналіз наукової літератури. Здійснено теоретичний аналіз причин і особливостей освітньої міграції здобувачів вищої освіти для навчання в зарубіжних закладах вищої освіти, автори виділяють дві основні стратегії поведінки студента при освітній міграції: 
отримання високої кваліфікації і стати затребуваним фахівцем на ринку праці або іммігрувати в країну, де він здобуває освіту.

Ключові слова: освіта, міграція, заклади вищої освіти, міграційні процеси, здобувачі вищої освіти.

Sedikova Iryna Oleksandrivna Doctor of Economics, Professor of the Department of Management and Logistics of the Odessa National Academy of Food Technologies, Kanatna str., 112, Odessa, 65039, tel.: (048) 712-41-14, e-mail: irinasedikova@ukr.net, https://orcid.org/0000-0001-5684-6927

Nikolyuk Olena Volodymyrivna Doctor of Economics, Professor of the Department of Management and Logistics of the Odessa National Academy of Food Technologies, Kanatna str., 112, Odessa, 65039, tel.: (048) 712-41-14, e-mail: alenavn11@gmail.com, https://orcid.org/0000-0002-1665-0361

\section{MIGRATION EDUCATIONAL PROCESSES IN UKRAINE}

Abstract. The article is devoted to the analysis of educational migration in the world and in Ukraine. According to the authors, educational immigration is of great social importance for many countries, in particular, has at least four key effects: social, political, demographic and economic.

The process of choosing a profession, studying in higher education institutions has become today for many students pragmatic, purposeful and appropriate changes taking place in society. Involving mainly young, well-educated people, migration processes increase the educational potential of the population of the recipient regions and reduce the indicators of the achieved educational level in the donor regions. For promising young people, emigration remains almost the only way to quickly improve their wellbeing without abandoning scientific activities.

In the context of increasing migration flows worldwide, educational migrants can be considered the most desirable category, as it is usually composed of young and enterprising people who are open and willing to accept new knowledge, technologies, national education and skills adapted to the local labor market. , adapted to the linguistic and cultural environment. Systematization of theoretical approaches to the study of this process and the study of migration trends allowed the author not only to identify the features of educational migration in the modern world, but also to establish transnational prospects for its development.

The article examines the main reasons underlying modern educational migration, in particular, obtaining higher education in foreign educational institutions. The authors consider the current state of educational migration, the importance of exports of Ukrainian higher education to the market of European countries. Theoretical analysis of the scientific literature was used as methods of this research. Theoretical analysis of the causes and features of educational migration of higher education students to study in foreign higher education institutions, the authors identify two main strategies of student behavior in educational migration: obtaining high qualifications and becoming a sought- 
after specialist in the labor market or immigrating to the country where he receives education.

Keywords: education, migration, higher education institutions, migration processes, educational program.

Постановка проблеми. Глобалізаційні процеси сучасного етапу розвитку впливають на міграційні процеси, мають як позитивні, так і негативні наслідки для країни. Міграція є багатоаспектним явищем, яке розглядається з позиції економіки, соціології, права і демографії іiі процеси впливають на народонаселення, рух капіталів, розвиток територій, формування правової і політичної культури суспільства.

Проблеми міграції населення вимагає глибоких досліджень 3 метою визначення основних чинників та мотивів, розробки заходів задля контролю та регулювання міграційних процесів в Україні. Надзвичайну загрозу соціальноекономічному розвитку країни являє особою освітня міграція, оскільки висококваліфіковані кадри, примноження інтелектуального капіталу, накопичення науково-технічного потенціалу $є$ підгрунтям економічно-соціального розвитку країни.

Аналіз останніх досліджень і публікацій. Українськими та зарубіжними вченими створено теоретичний фундамент досліджень сутності міграції, іï функцій, умов виникнення та інструментів управління. Вивченню понять «міграція», «трудова міграція» присвячені роботи Дж. Аранго, Дж. Борхаса, К. Босвелла, Р. Лалонде, С. Кастельса, Т. Заславської, Л. Рибаковського, А. Топіліна, В. Бобкова, С. Іноземцева. Значний внесок у розвиток теорії та практики управління міграцією, аналізу їі впливу на економіку країни внесли такі вітчизняні вчені, як Д. Валента, Т. Заславська, Ж. Зайончковська, В. Переведенцев, Н. Рімашевський та ін.

Мета статті. Незважаючи на численні публікації останніх років в Україні, науковці багато уваги у своїх дослідженнях приділяють трудовій міграції, залишаючи при цьому без достатньої уваги дослідження проблеми освітньої міграції. Метою даного дослідження є визначення головних причини, що лежать в основі сучасної освітньої міграції, зокрема, отримання вищої освіти в зарубіжних навчальних закладах, визначити значення експорту української освіти на світовий ринок.

Виклад основного матеріалу. Міграція (від лат. migratio - переселення), у науково-довідковій літературі визначається як «переміщення населення в межах однієї країни або з однієї країни в іншу»[1]. Досить типовим і поширеним $\epsilon$ визначення міграції як «переміщення людей через кордони певних територій зі зміною місця проживання назавжди або на більш чи менш тривалий час» [2].

Широке коло трактування поняття «міграція» вимагає його систематизації. На сьогоднішній день науковці виокремлюють такі підходи до визначення даної дефініції, а саме:

1. Види руху населення, які мають суспільне значення, включаючи процеси просторового переміщення людей, соціальні процеси, об’єднаних територіальною ознакою; 
2. Просторове переміщення населення, незалежно від цілей та характеру;

3. Просторове явище, яке включає переміщення людей між населеними пунктами зі зміною (постійною чи тимчасовою) місця проживання, а також регулярний двосторонній рух між місцями проживання та праці;

4. Процес просторового руху людей, який веде до територіального перерозподілу населення.

Отже, як визначає М. Денисенко «міграція у широкому значенні слова - це територіальний рух населення між населеними пунктами (безповоротний, маятниковий сезонний)» [3].

Міжнародна міграція робочої сили стрімко розвивається в останні десятиріччя. Кількість мігрантів у 2001 р. у світі складала 140 млн. чоловік, у 2005 p. - 191 млн., у 2014 р. - 232 млн., у 2019 р. - 272 млн. За даними Міністерства соціальної політики України, кількість українців, які перебувають на постійному працевлаштуванні за кордоном складає 3,2 мільйона осіб. Це $18 \%$ всього економічно-активного населення країни [14]. Світовий Банк прогнозує, що кількість мігрантів у світі збільшиться на $3 \%$ до 2025 року $[4,5,6]$.

Динаміка розвитку сучасного суспільства створює для всіх соціальних суб'єктів не тільки можливості, а й необхідність змін свого місця в суспільстві. Соціальні переміщення, мобільність $є$ невід'ємною характеристикою суспільства 3 високошвидкісними перетворювальними тенденціями. Пов'язана 3 отриманням освіти мобільність, стає актуальною у зв'язку з потребами індивідів в ефективному освоєнні соціальних обставин, які постійно оновлюються.

Освітня міграція - переміщення учнів, студентів, аспірантів, докторантів, фахівців, що підвищують кваліфікацію задля отримання певного рівня освіти, орієнтовані на заклади освіти, що має різні терміни тривалості. Одна 3 причин міграції молоді полягає в бажанні розвиватися, реалізовуватися за курсом освіти, отримати міжнародну освіту.

Цінність освіти як самостійного соціального феномена, що має соціокультурну, особистісну і статусну привабливість, відступила на другий план. Статистика свідчить, що майбутні студенти віддають перевагу державними закладам $(80 \%)$, приватним - $15 \%$, комунальним - $5 \%$. Самими затребуваними $\epsilon$ такі спеціальності як філологія, менеджмент, економіка та право, водночас за цими спеціальностями, спостерігався надлишок випускників і тому МОН України щорічно зменшує державне замовлення, водночас збільшилась подача заяв абітурієнтів на технічні спеціальності (див. мал. 1). 


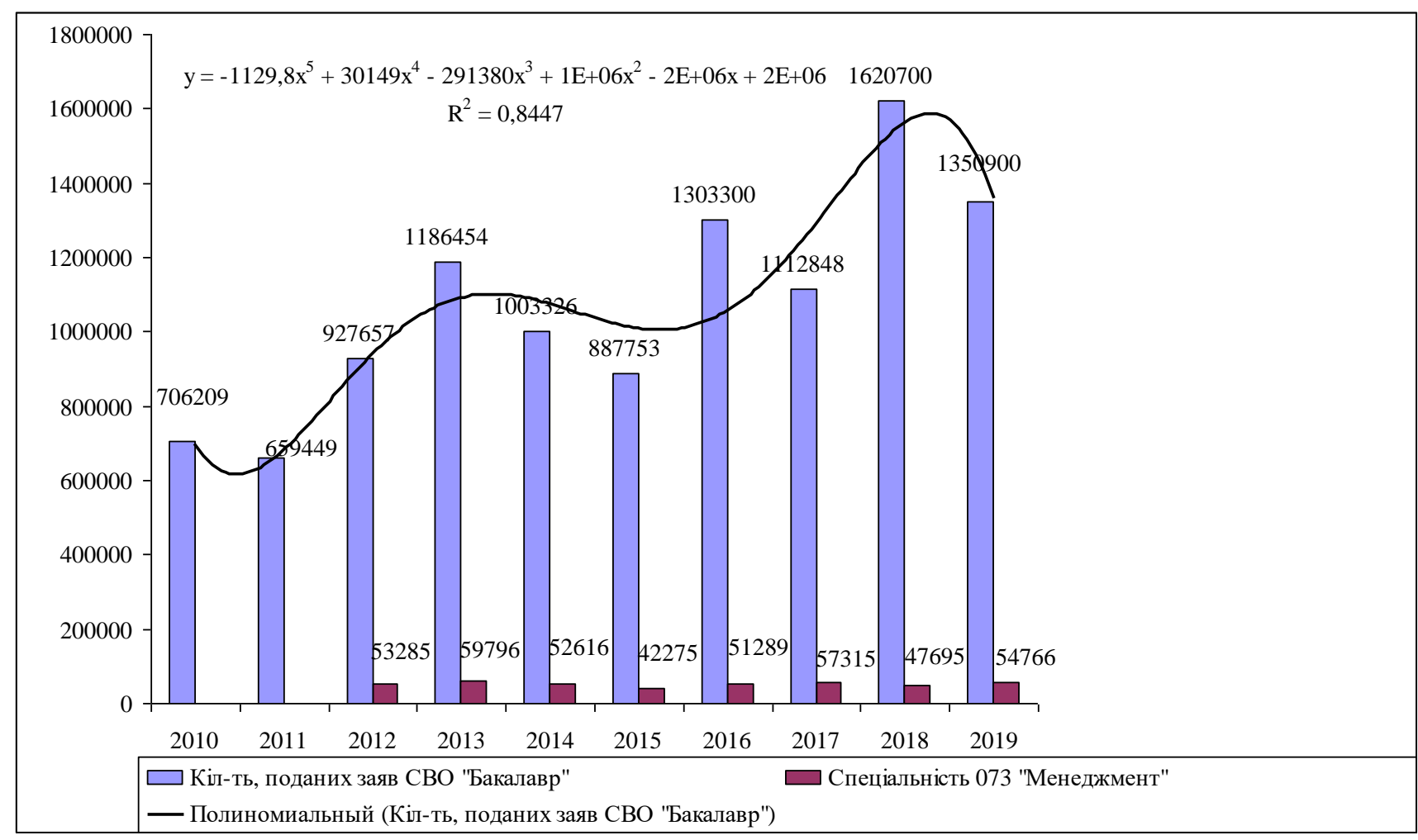

Мал. 1. Кількість поданих заяв СВО «Бакалавр» на спеціальність 073 Менеджмент» у 2010-2019 рр.*

* розраховано авторами за даними Інтернет-порталу : www.vstup.info

У загальному розумінні академічна мобільність $є$ тимчасове переміщення студента для отримання специфічних знань, академічної підготовки з обов'язковим наступним поверненням до місця постійного навчання, проживання. Така мобільність стає освітньої або навчальної міграцією, за визначенням Є. Самофалової, «... залученням індивідів в соціально-географічні переміщення 3 метою отримання освіти» [7]. Якщо освітні мігранти не повертаються в рідні місця для завершення освіти або працевлаштування, а прагнуть зробити своє академічне географічне переміщення безповоротним, то така освітня міграція стає некомпенсованою. Некомпенсований характер освітньої міграції створюється тим, що міграційний спад населення країни або іiі регіону не заповнюється припливом на цю територію нових мігрантів, які мають освітні наміри. За класифікацією, розробленою С. Градировським та Т. Лопухіною [8], освітню міграцію, яка не компенсується можна віднести до добровільної, оскільки вона $є$ вільним індивідуальним вибором. Освітня міграція, яка не компенсується є безповоротною, ii наслідком стає постійне проживання студента в пункті переміщення і після закінчення закладу освіти.

За результатами проведеного соціологічного дослідження «Молодь України 2018» - 56 \% української молоді хочуть жити в Україні, 20 \% опитаних виявили бажання попрацювати за кордоном якийсь час, але потім повернутися в Україну, 7 $\%$ - хотіли б навчатися за кордоном, але потім повернутися в Україну, проте 17 \% молоді віком 14-34 роки шукають можливості для еміграції з України. 
Ведення діяльності закладів вищої освіти (ЗВО) на ринку освітніх послуг в Україні здійснюється в умовах жорсткої конкуренції та залежності від державного регулювання (акредитація, ліцензування), що призводить до ризиків, пов'язаних зі зміною умов функціонування.

Відповідно до відкритих у вільному доступі даних Державної служби статистики України, у 1990-1991 н. р. в Україні, нараховувалося 149 3ВО, загальний контингент складав 881300 студентів. Така кількість 3ВО та здобувачів вищої освіти на початку незалежності України були спадком радянської системи вищої освіти, що припинила своє існування. У 2000-2001 н.р. таких 3ВО було 315, загальний контингент складав 1402900 осіб [9].

До 2010 року кількість ЗВО за рахунок насамперед приватних і розширення мережі відокремлених структурних підрозділів зростала, незважаючи на суттєве скорочення кількості випускників шкіл і загальний спад економіки країни, яка була не спроможна достатньою мірою профінансувати таку мережу 3ВО [9]. За даними єдиної державної бази сприянню освіти станом на листопад 2019 р. в Україні нараховувалось усього 671 заклад вищої освіти: 193 університети, 152 інститути, 127 відокремлених підрозділів, 118 інших наукових установ (організацій), 73 академії та 8 наукових центрів [9].

Проявом інноваційних змін, що відбуваються в структурі та якості міграційних процесів, виступає зміна освітнього рівня населення під впливом міграцій. Залучаючи переважно молодих, добре освічених людей, міграційні процеси сприяють підвищенню освітнього потенціалу населення регіонівреципієнтів і зниженню показників досягнутого освітнього рівня в регіонахдонорах. Для перспективної молоді еміграція залишається чи не єдиним шляхом швидкого поліпшення добробуту без відмови від наукової діяльності. Разом із тим збільшилася кількість емігрантів, які мають учений ступінь кандидата наук. Найбільшу кількість кандидатів наук Україна втрачає в міграційному обміні зі Сполученими Штатами, Росією, Німеччиною та Канадою [10].

Відповідно дослідження, проведеного аналітичним центром «CEDOS», у 2016-2017 н. р. нараховувалося 77424 особи з українським громадянством, які навчалися у закордонних університетах. Це становило приблизно 8 \% від загальної кількості тих, хто вчиться на денних програмах вищої освіти в Україні. [9]

Традиційно наші співвітчизники обирають заклади вищої освіти Польщі, Російської Федерації, Німеччини, Канади, Чехії, Італії, США, Іспанії, Австрії, Франції, Словаччини, Болгарії. Загалом протягом останніх років кількість українців, що виявила бажання навчатися у закордонному університеті, зросла більш ніж утричі - 324104 до 77424 осіб. Конкретні дестинації навчання, відповідно до статистичних даних: понад 33 тис. українських студентів навчається в Республіці Польща (це 55 \% від усього іноземного студентства; водночас, це також країна з найвищим показником трудових мігрантів з України), близько 10 тис. - у Німеччині, понад 17 тис. - в інших європейських країнах [9].

В умовах посилення міграційних потоків у світовому масштабі освітніх мігрантів можна вважати найбажанішою категорією, оскільки, як правило, іiі складають молоді та ініціативні люди, які відрізняються відкритістю і готовністю сприймати нові знання, технології, які отримують національну освіту та 
кваліфікацію, пристосовані до місцевого ринку праці, адаптовані до мовного та культурного середовища. Як свідчать зарубіжні дослідження, освітні мігранти $\epsilon$ однією з найбільш адаптованих груп мігрантів. Невипадково міграційна політика багатьох країн світу розглядає іноземних студентів як одну 3 найбільш бажаних категорій іммігрантів. Потік людського ресурсу тягне за собою потоки матеріальних і фінансових коштів, необхідних для існування закладів освіти. Наприклад, в німецьких університетах навчається багато українських студентів, однак вони складають всього 3 \% від усього іноземного студентства. Тому, якщо їхня кількість зменшиться, ця зміна не буде відчутною для німецьких університетів. Німецькі заклади успішно диверсифікують притоки студентства 3 різних країн, тому жодна 3 них не складає більше $10 \%$ від усього іноземного студентства.

Натомість українське студентство є стратегічно важливими для Польщі, де воно складає 55 \% від усього іноземного студентства. 3 огляду на те, що більшість 3 них самі сплачують навчання, проживання, це $є$ важливими інвестиціями для Польщі, які компенсують демографічний спад та виїзд польської молоді до закладів вищої освіти в інші країни СС.

У Словаччині, українське студентство, за даними 2018-2019 н.р., складало 30 \%. Всі вони навчаються за кошти словацького бюджету, тобто вони, як і словацькі громадяни, приносять бюджетні кошти словацьким університетам, натомість проживання оплачують власними коштами. Ми можемо припустити, що словацькі університети також будуть розширювати свою рекрутацію в Україні.

Стрімке зростання українського контингенту вказує на їхню важливість для болгарських університетів, особливо для бакалаврських програм, де студенти 3 атестатом української школи складають 20 \% від усіх, хто здобув середню освіту за межами Болгарії.

Освітня міграція сьогодні має високий ступінь інтенсивності, що обумовлено об'єктивними чинниками:

По-перше, посилюється інтеграція освітніх систем, викликана потребами глобальної політики і економіки.

По-друге, підвищення значущості освіти в результаті переходу до інформаційного суспільства (суспільства знань).

По-третє, необхідність безперервної освіти (освіти протягом життя) та постійного підвищення кваліфікації як відповідь на дедалі зростаючу конкуренцію на ринку робочої сили.

По-четверте, розвиток інформаційних технологій, що дозволяють закладам вищої освіти збільшувати свою інформаційну відкритість для потенційних здобувачів.

По-п’яте, освітня політика багатьох держав, спрямована на інтенсифікацію освітньої міграції, підвищення доступності освітніх послуг, інтернаціоналізацію освітнього середовища. Створення та ефективне функціонування міжнародних програм студентського обміну (Еразмус + ).

Інтенсивність освітньої міграції викликана об'єктивними причинами. Не викликає сумнівів припущення, що потоки освітньої міграції будуть все більш 
інтенсивними і різноманітними, питання тільки в тому, яку роль буде займати українська освіта освіту в цьому процесі.

На сьогодні ситуація оцінюється наступним чином: лідер на світовому освітньому ринку США (ємність якого за оцінками СОТ - 60 млрд. доларів), які контролюють майже третину світового фінансового освітнього обороту. Національна дослідницька рада Іспанії опублікувала міжнародний рейтинг університетів світу Ranking Web of Universities (Webometrics) (див. табл. 1). Головна ідея рейтингу полягає в оцінюванні наукової, навчальної та соціальної місії університетів опосередковано через показники представленості університету у веб-просторі.

Таблиця 1

\begin{tabular}{|l|l|l|l|l|l|}
\hline $\begin{array}{l}\text { Світовий } \\
\text { рейтинг }\end{array}$ & \multicolumn{1}{|c|}{ ЗВО } & $\begin{array}{l}\text { Presence } \\
\text { Rank }\end{array}$ & $\begin{array}{l}\text { Impact } \\
\text { Rank }\end{array}$ & $\begin{array}{l}\text { Openness } \\
\text { Rank }\end{array}$ & $\begin{array}{l}\text { Excellence } \\
\text { Rank }\end{array}$ \\
\hline 1147 & $\begin{array}{l}\text { Київський національний } \\
\text { університет Тараса Шевченка }\end{array}$ & 728 & 1802 & 1152 & 1345 \\
\hline 1489 & $\begin{array}{l}\text { Національний технічний } \\
\text { університет України Київський } \\
\text { політехнічний інститут }\end{array}$ & 403 & 1098 & 1281 & 2678 \\
\hline 1929 & $\begin{array}{l}\text { Сумський державний } \\
\text { університет }\end{array}$ & 1109 & 2494 & 1553 & 2742 \\
\hline 2259 & $\begin{array}{l}\text { Харківський національний } \\
\text { університет В. Н. Каразіна }\end{array}$ & 1203 & 3594 & 4228 & 2294 \\
\hline 2423 & $\begin{array}{l}\text { Тернопільський національний } \\
\text { економічний університет }\end{array}$ & 1001 & 1208 & 1509 & 4389 \\
\hline 2469 & $\begin{array}{l}\text { Національний технічний } \\
\text { університет Харківський } \\
\text { політехнічний інститут }\end{array}$ & 1090 & 4465 & 1436 & 3018 \\
\hline 2993 & $\begin{array}{l}\text { Національний гірничий } \\
\text { університет }\end{array}$ & 2325 & 3864 & 2483 & 3926 \\
\hline 3018 & $\begin{array}{l}\text { Національний університет } \\
\text { Львівська політехніка }\end{array}$ & 1142 & 4406 & 7356 & 2097 \\
\hline 3112 & $\begin{array}{l}\text { Харківський національний } \\
\text { університет радіоелектроніки }\end{array}$ & 2765 & 8240 & 1962 & 2956 \\
\hline 3289 & $\begin{array}{l}\text { Львівський національний } \\
\text { університет Івана Франка }\end{array}$ & 1255 & 3235 & 7356 & 3092 \\
\hline
\end{tabular}

Рейтингове агентство Центр міжнародних проектів «Свроосвіта» [12], в партнерстві 3 міжнародною групою експертів IREG Observatory on Academic Ranking and Excellence [13], презентував академічний рейтинг закладів вищої освіти України III, IV рівнів акредитації «Топ-200 Україна 2019». Лідерами рейтингу кращих закладів вищої освіти в Україні стали: Національний університет «Львівська політехніка», Львівський національний університет імені Івана Франка, Національний технічний університет «Дніпровська політехніка», Національний технічний університет «Харківський політехнічний інститут», Харківський національний університет ім. В. Н. Каразіна, Національний технічний університет України «Київський політехнічний інститут імені Ігоря Сікорського», Київський 
національний університет імені Тараса Шевченка, Національний аерокосмічний університет імені М. Є. Жуковського «Харківський авіаційний інститут», Національний університет біоресурсів і природокористування України, Сумський державний університет.

При розробці напрямів і механізмів освітньої міграційної політики потрібно враховувати такі особливості цього виду міграції: територіальна локалізація (міграція здійснюється на ті території і в ті населені пункти, де є навчальні заклади, які здійснюють навчання іноземців); тимчасова локалізація (період міграції фіксований і залежить від періоду навчання); вікова гомогенність (мігранти приблизно рівні за віком). Ці особливості вказують на те, що освітня міграція є більш «прозорою» і легше піддається міграційному обліку, що дозволяє здійснювати цілеспрямовану політику підтримки цього міграційного потоку.

Фролов С. [15] виділяє три групи чинників міграційної рухливості:

1) фактори виштовхування, пов'язані з незадовільними або важкими умовами існування на рідній території;

2) фактори тяжіння, що включають сукупність привабливих рис або умов проживання на новому місці;

3) фактори шляхів міграції, що представляють собою характеристики безпосереднього пересування мігранта з одного регіону в інший [15].

У ситуації освітньої міграції необхідно враховувати, на наш погляд, всі ці групи. Серед чинників виштовхування можна виділити наступні: відсутність необхідної освітньої програми, висока плата за навчання, незадовільна якість освіти, складність працевлаштування 3 даними дипломом.

До факторів тяжіння для освітніх мігрантів відносяться: доступна плата за навчання, висока якість освіти, унікальна освітня програма, можливість працевлаштування в країні навчання, використовувати отримані знання в рідній країні, престиж диплома освітнього закладу.

Шляхи міграції можуть включати в себе наступні елементи: наявність освітніх грантів, знання мови навчання, можливість поєднувати освітні програми в своєму навчальному закладі 3 іноземним, в тому числі реалізація програм подвійного диплому, економічне становище здобувача вищої освіти, організаційні чинники.

Як було зазначено, до чинників, що впливають на прийняття рішення до навчання в зарубіжному закладі вищої освіти, відноситься наявність освітніх грантів. Грант являє собою фінансову допомогу, яку отримує талановита молодь, наукові співробітники для навчання та роботи. Дані кошти надаються 3 різних джерел (органи влади, благодійні організації, комерційні організації тощо). Надання грантів допомагає забезпечити підготовку висококваліфікованих кадрів, тому організації, які розподіляють їх, зацікавлені в високому рівні підготовки здобувачів.

Важливим фактором для потенційних освітніх мігрантів $\epsilon$ рівень толерантності в приймаючому суспільстві. Толерантність розглядається як «повага прав іншої людини за умови, що він також поважає ваші права» [16].

Висновки. На закінчення слід зазначити, що населення України формують три процеси: смертність, народжуваність та міграція. Виходячи 3 чого зусилля 3 боку держави повинні бути спрямовані не тільки на збільшення народжуваності та 
скорочення смертності, а й на стимулювання інтелектуальної імміграції, яка здатна привести до економічних, політичних і соціальних змін в країні.

Для зменшення освітньої міграції необхідне провадження системи заходів, які повинні мати чітке внутрішнє і зовнішнє спрямування. Перш за все необхідно вжити низку заходів, спрямованих на макроекономічну стабілізацію та оздоровлення економіки: створення робочих місць, розширення іноземного інвестування тощо.

Зовнішні заходи мають забезпечити цивілізовані форми виїзду працівників за кордон та можливість їх вільного повернення з-за кордону, а також гарантії нашим співвітчизникам захисту їхніх прав за кордоном. Інтелектуальна міграція в рівній мірі може бути застосована до різних наук, які мають свою специфіку. Інтелектуальні ресурси є непоправних багатством країни, тому одним із головних завдань державної політики має стати залучення вчених і фахівців 3 різних регіонів.

\section{Лimepamypa:}

1. Новий словник іншомовних слів: близько 40000 слів / за ред. Л. І. Шевченко.К: АРІЙ, 2008. 384 c.

2. Кравців В. С., Садова У. Я. Міграційні явища та процеси: поняття, методи, факти: довідник / за ред. Л. І. ШевченкоЛьвів: Інститут регіональних досліджень НАН України, 2009. 66 c.

3. Денисенко М. Б. МиграциологияМ: Изд-во МГУ, 2014. 145 с.

4.ООН опубликовала доклад о том, что происходило с международной эмиграцией в условиях кризиса // Демоскоп Weekly: [Веб-сайт]. Москва, 2010. URL: http://demoscope.ru/weekly (дата обращения:09.08.2020).

5. Global Economic Prospects [Electronic resource] // The International Bank for Reconstruction and Development, 2006.- World Bank. - 182 p.- Mode of access: https://openknowledge.worldbank.org/bitstream/handle/10986/7306/343200

6. Migrant_Stock_Documentation_2005.pdf; Wickramasekara P. Globalisation, International Labour Migration and the Rights of Migrant Workers / P. Wickramasekara // Third World Quarterly.2008.- Vol. 29, № 7.- P. 1247-1264.

7. Самофалова Е.И. Образовательная миграция: проблемное поле и основные характеристики [Электронный ресурс] // Научная сеть SciPeople. URL: http://scipeople.ru/publication/69692/ (дата обращения: 09.07.2020)

8. Градировский С., Лопухина Т. Типологии миграционных процессов [Электронный pecypc] // Государство и антропоток. URL: http://antropotok.archipelag.ru/text/a302.htm (дата обращения: 09.07.2020)

9. Річний звіт Національного агентства із забезпечення якості вищої освіти за 2019 рік / за заг. ред. проф. Сергія Квіта. - Київ : Національне агентство із забезпечення якості вищої освіти, 2020. - 244 с.

10. Міграція в Україні. Факти i цифри. URL: http://www.slideshare.net/presscvua/factsfigures-b5-uaf.

11. [Веб-сайт]. Одеса, 2020. URL: https://cedos.org.ua/uk/articles/ukrainske-studentstvo-zakordonom-dani-do-201718-navchalnoho-roku(дата звернення: 14.08.2020).

12. [Веб-сайт]. Одеса, 2020. URL: http:// http://www.euroosvita.net (дата звернення: 14.08.2020).

13. [Веб-сайт]. Одеса, 2020. http://ireg-observatory.org/en/ URL: http:// http://www.euroosvita.net (дата звернення: 14.08.2020). 
14. Майже кожен 5-й українець працездатного віку перебуває на заробітках. https://hromadske.ua/posts/majzhe-kozhen-5-j-ukrayinec-pracezdatnogo-viku-perebuvaye-nazarobitkah-uryad

15. Фролов С. Соціологія: підручник для вищих навчальних закладів. К.: Знання, 2014

16. Почебут Л.Г. Крос-культурна і етнічна психологія. СПб .: Пітер, 2012

\section{References:} $384 \mathrm{~s}$

1. Noviy slovnik inshomovnikh sliv: bliz`ko 40000 sliv / za red. L. I. Shevchenko.K: ARIY, 2008.

2. Kravtsiv V. S., Sadova U. Ya. Mihratsiyni yavishcha ta protsesi: ponyattya, metodi, fakti: dovidnik / za red. L. I. Shevchenko/ L`viv: Institut rehional`nikh doslidzhen`NAN Ukrayini, 2009. 66 s.

3. Denisenko M. B. MihratsiolohiyaM: Izd-vo MHU, 2014. 145 s.

4. OON opublikovala doklad o tom, chto proiskhodilo $\mathrm{s}$ mezhdunarodnoy emihratsiey $\mathrm{v}$ usloviyakh krizisa // Demoskop Weekly: [Veb-sayt]. Moskva, 2010. URL: http://demoscope.ru/weekly (data obrashcheniya: 09.08.2020).

5. Global Economic Prospects [Electronic resource] // The International Bank for Reconstruction and Development, 2006.- World Bank. - 182 p.- Mode of access: https://openknowledge.worldbank.org/bitstream/handle/10986/7306/343200

6. Migrant_Stock_Documentation_2005.pdf; Wickramasekara P. Globalisation, International Labour Migration and the Rights of Migrant Workers / P. Wickramasekara // Third World Quarterly.2008.- Vol. 29, № 7.- P. 1247-1264.

7. Samofalova E.Y. Obrazovatelnaia myhratsyia: problemnoe pole y osnovnыe kharakterystyky [Эlektronnыi resurs] // Nauchnaia set SciPeople. URL: http://scipeople.ru/publication/69692/ (data obrashchenyia: 09.07.2020)

8. Hradyrovskyi S., Lopukhyna T. Typolohyy myhratsyonnыkh protsessov [Elektronnыi resurs] // Hosudarstvo y antropotok. URL: http://antropotok.archipelag.ru/text/a302.htm (data obrashchenyia: 09.07.2020)

9. Richnyi zvit Natsionalnoho ahentstva iz zabezpechennia yakosti vyshchoi osvity za 2019 rik / za zah. red. prof. Serhiia Kvita. - Kyiv : Natsionalne ahentstvo iz zabezpechennia yakosti vyshchoi osvity, 2020. - $244 \mathrm{~s}$.

10. Mihratsiia v Ukraini. Fakty i tsyfry. URL: http://www.slideshare.net/presscvua/factsfiguresb5-uaf.

11. [Veb-sait]. Odesa, 2020. URL: https://cedos.org.ua/uk/articles/ukrainske-studentstvo-zakordonom-dani-do-201718-navchalnoho-roku(data zvernennia: 14.08.2020).

12. [Veb-sait]. Odesa, 2020. URL: http:// http://www.euroosvita.net (data zvernennia: 14.08.2020).

13. [Veb-sait]. Odesa, 2020. http://ireg-observatory.org/en/ URL: http:// http://www.euroosvita.net (data zvernennia: 14.08.2020).

14. Maizhe kozhen 5-y ukrainets pratsezdatnoho viku perebuvaie na zarobitkakh. https://hromadske.ua/posts/majzhe-kozhen-5-j-ukrayinec-pracezdatnogo-viku-perebuvaye-nazarobitkah-uryad

15. Frolov S. Sotsiolohiia: pidruchnyk dlia vyshchykh navchalnykh zakladiv. K.: Znannia, 2014

16. Pochebut L.H. Kros-kulturna i etnichna psykholohiia. SPb .: Piter, 2012 